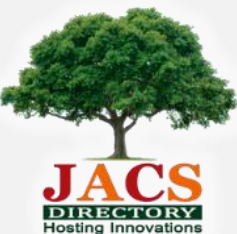

Journal of Nanoscience and Technology

\title{
Fabrication and Characterization of Dye-Sensitized Solar Cell using Chemically Grown ZnS Nanoparticles
}

\author{
Kamal Bera*, Satyajit Saha, Paresh Chandra Jana \\ Department of Physics and Technophysics, Vidyasagar University, Paschim Medinipur - 721 102, West Bengal, India.
}

\section{A R T ICLE DETAILS}

Article history:

Received 21 August 2018

Accepted 29 August 2018

Available online 30 August 2018

\section{Keywords:}

ZnS Nanoparticle

Device Fabrication

Optical Absorption

DSSC

\begin{abstract}
A B S T R A C T
In this work, we have fabricated dye-sensitized solar cell (DSSC) based on chemically grown ZnS nanoparticles with three different source of dye namely Gerbera jamesonii, Rosa indica and Acalypha wilkesiana leaves extract. Anthocyanin, a kind of natural dye found in the leaves of plants and flowers was used as photosensitizers in preparing dye-sensitized solar cell. The optical properties of anthocyanin present in three dyes were also studied. Morphological properties have been studied by atomic force microscopy on $\mathrm{ZnS}$ film as well as on $\mathrm{ZnS}$ film with dye. The current-voltage characteristics of the dye-sensitized solar cell had been studied in light condition. The DSSC is characterized by the measurement of open circuit voltage, short circuit current density; efficiency and fill factor. The efficiency of three dye solar cell is different and it is maximum for Acalypha wilkesiana leaves extract dye.
\end{abstract}

\section{Introduction}

The energy crisis in the current world has led the researcher to find renewable energy sources. And the finding is nonconventional sources like solar energy. The solar energy can be used by the photovoltaic device. The current research strategy is to fabricate low-cost photovoltaic devices and increase its efficiency [1-8]. The semiconducting nanoparticles are most hopeful material for application in the solar cell due to their exciting structural, optical and electronic etc. properties which is differ from bulk [9-11].

Zinc sulfide, a group II-VI semiconductor is most frequently used as phosphor material [12]. It has tremendous applications in the field of electronics, photonics devices such as light emitting diodes [13], solar cells [14], electroluminescence [15], photo detectors [16] and biosensors [17]. Dye-sensitized solar cells (DSSC) are rising as a low-cost photovoltaic device [18]. Such a low-cost photovoltaic device are the future of large power production from non-conventional energy sources. DSSC converts the photon from solar energy to electricity Different biological strategies have been taken to increase the efficiency of the device. DSSC have four components as follows: (1) solar energy absorber containing the electrode dye-sensitized layer (2) the transparent conductive oxide layer that facilitates charge transfer from the electrode layer (3) graphite paint on ITO glass act as counter electrode (4) the redox electrolyte layer for reducing the level of energy supplied from the dye molecules [4, 5, 19-25]. DSSC composed of nano-ZnS layer acting as the electron carrier and the organic dye layer as electron generator, which will regain to its original state by taking electron donated by the electrolyte solution.

We have adopted a simple chemical reduction method to grow $\mathrm{ZnS}$ nanoparticles [26]. The DSSC has been fabricated using ZnS nanomaterials. The natural dyes were extracted from Gerbera jamesonii, Rosa indica and Acalypha wilkesiana leaves of plant. The value of fill factor and efficiency of the ZnS based DSSC device are determined. The used method is highly cost-effective and free from environmental hazards.

\section{Experimental Methods}

\subsection{Preparation of ZnS Nanoparticle}

The ZnS nanoparticle has been synthesized using a cost-effective chemical reduction technique [26]. Zinc chloride, sulfur powder and sodium borohydride were used to grow $\mathrm{ZnS}$ nanoparticles at room temperature as reported elsewhere [27]. The synthesized nanoparticles are structurally and optically characterized using transmission electron microscope, x-ray diffraction, UV-Vis absorption spectroscopy, photoluminescence spectroscopy.

\subsection{Preparation of Bio Dye Sensitizer}

Fresh red flower of Gerbera jamesonii, Rosa indica and red leaves of Acalypha wilkesiana plant are collected in the morning from Vidyasagar University campus, West Bengal, India. The collected material washed in running tap water and then with distilled water for several times. Then cleaned material placed in a vacuum furnace for 3 hours at $50^{\circ} \mathrm{C}$ to remove the moisture. $5 \mathrm{~g}$ of each dried sample is separately crushed with a porcelain mortar and pestle. Then each crushed material is dissolved in 20 $\mathrm{mL}$ ethanol without exposure of light. After extraction, dye solutions are taken by filtering extraction. Finally pure and clear dye solution is made for use as sensitizers in sensitizing ZnS electrode.

\subsection{Device Fabrication}

First two indium doped tin oxide (ITO) glass plates are cleaned with acetone in an ultrasonicator. After ultrasonication ITO coated glass are dried. $\mathrm{ZnS}$ nanoparticle of $1 \mathrm{~g}$ weight is mixed with $1 \mathrm{~mL}$ acetic acid $\mathrm{ch}$ 3-4) and grinded in mortar for making paste. The lump free pestle of $\mathrm{ZnS}$ nanoparticle is now prepared. Teflon tape was warped on glass plate to control film size and making electrical contact. Now $\mathrm{ZnS}$ paste is deposited on the conducing surface of ITO glass uniformly by doctor blade method. The coated films are dried at room temperature for 30 minutes then fired for $30 \mathrm{~min}$ at $100{ }^{\circ} \mathrm{C}$ in a vacuum furnace to increase the internal voids of film organization and enhance its absorption performance. The resulting film thickness was about $1 \mathrm{~mm}$ of width and $1 \mathrm{~cm}^{2}$ of area. After hightemperature annealing the film was cooled down to room temperature. The ZnS film is now dipped in previously prepared bio dyes. To make complete adsorption of dye, the film was dipped for 6 hours of time.

Graphite paint is made on the conducting surface of other ITO glass, which act as cathode. A redox electrolyte is prepared using $0.5 \mathrm{~mol}$ of $\mathrm{KI}$, $0.05 \mathrm{~mol}$ of $\mathrm{I}_{2}$, and $0.5 \mathrm{~mol}$ of acetic acid.

The two prepared electrodes of ITO coated glass are then sandwiched using two binder clips. Three drops of electrolyte solution is injected into the gap of two glasses to serve as a conductor to electrically connect the two electrodes. The schematic diagram of the dye sensitized solar cell mechanism is displayed in Fig. 1. 


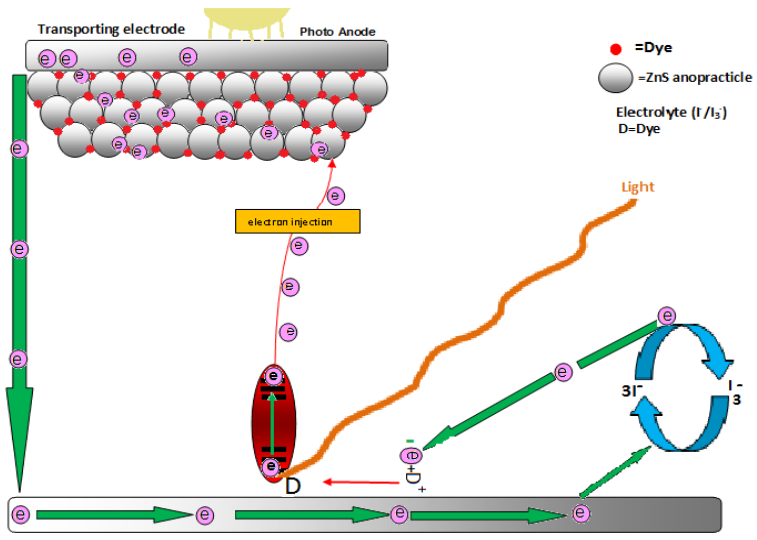

Fig. 1 The schematic diagram of the dye sensitized solar cell

\subsection{Characterization}

The structural characterization of the as prepared samples is performed using transmission electron microscope (TEM) and X-ray diffraction (XRD). The optical absorption study of these dyes was recorded in the range of $200 \mathrm{~nm}-900 \mathrm{~nm}$ using a Shimadzu Pharmaspec 1700 UV-VIS spectrophotometer. Atomic force microscopy study has been done on $\mathrm{ZnS}$ film as well as on $\mathrm{ZnS}$ film with adsorbing dye. Anthocyanin acts as sensitizer in the fabricated device which is collected from red flower of Gerbera jamesonii, Rosa indica and red leaves of Acalypha wilkesiana plant. The performance of prepared DSSCs was characterized by measuring the current density (J)-voltage (V) curves under illumination with white light $\left(100 \mathrm{~mW} \mathrm{~cm}^{-2}\right)$. The short circuit current density (JSC), open circuit voltage (VOC), fill factor (FF), and power conversion efficiency $(\eta)$ are measured from the J-V graphs. All he measurement was done with the help of a potentiometer and digital multimeters.

\section{Results and Discussion}

\subsection{Structural Study}

The TEM image of as synthesized $\mathrm{ZnS}$ nanoparticles is shown in Fig. 2. The grown nanoparticles are agglomerated and the average size of the nanoparticles is found to be $10 \mathrm{~nm}$.

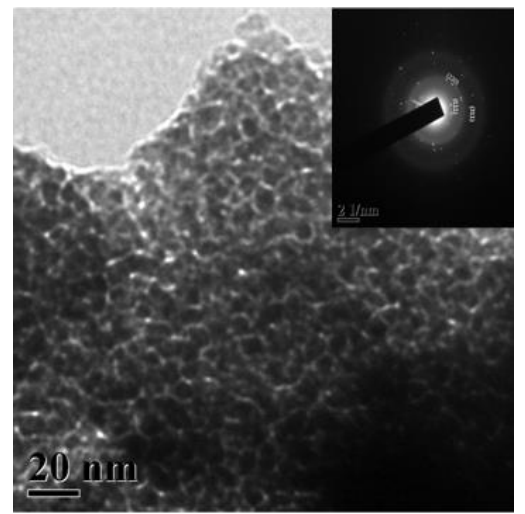

Fig. 2 The TEM Image and SAED pattern of as prepared nanoparticles

The XRD pattern of ZnS nano particles is shown in Fig. 3. The XRD pattern of the as prepared samples shows that the as grown $\mathrm{ZnS}$ nanoparticles are in cubic phase.

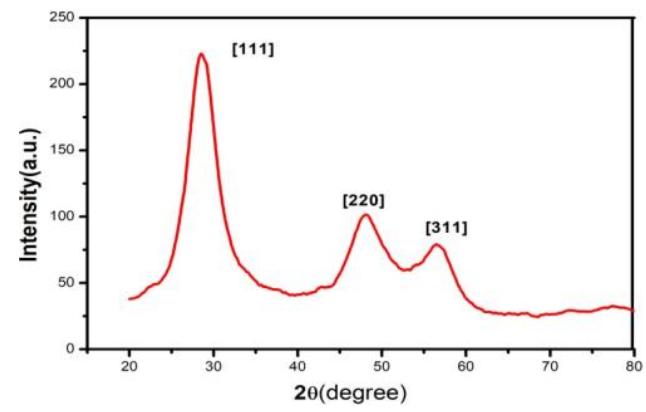

Fig. 3 XRD pattern of as synthesized $\mathrm{ZnS}$ nanoparticles https://doi.org/10.30799/jnst.155.18040506

\subsection{Optical Absorption Study}

The optical absorbance spectra of the prepared $\mathrm{ZnS}$ nanoparticles and different bio dyes are shown in Figs. 4 and 5. The corresponding band gap of $\mathrm{ZnS}$ nanoparticle are also calculated inset of Fig. 4 using the $(\alpha \mathrm{hv})^{2}$ vs $h v$ plot, where $\alpha$ is absorption coefficient, h is Plank constant and $v$ is the frequency of light.

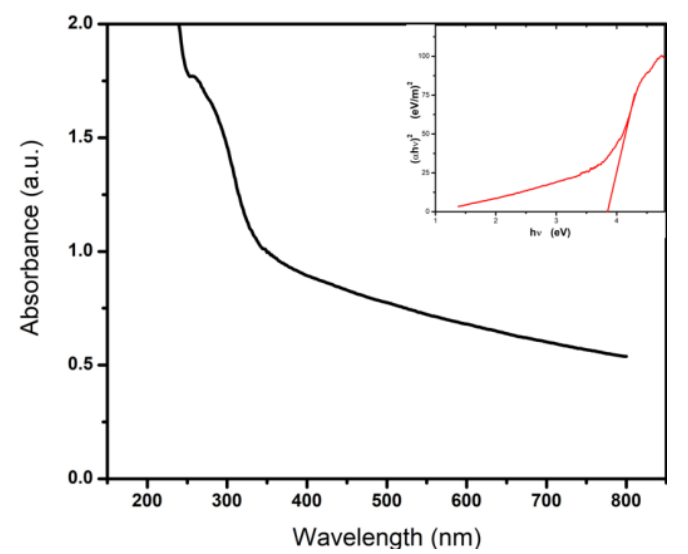

Fig. 4 Optical absorption spectrum of Zns nanoparticles and band gap determining (inset) plot

Among three bio dyes, Acalypha wilkesiana gives maximum absorbance on $550 \mathrm{~nm}$. Whereas Gerbera jamesonii gives minimum absorbance. There were other absorption peaks close to $450 \mathrm{~nm}$ corresponding to different dyes. So optical absorbance spectra provide light absorption information between the dye ground state and excited states.

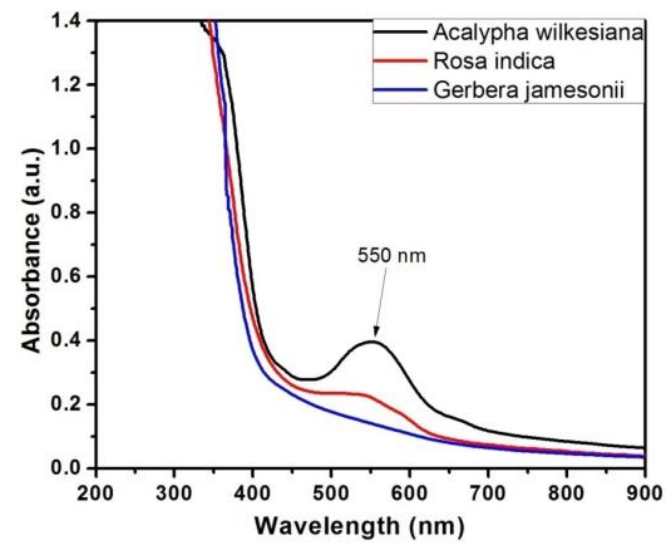

Fig. 5 Optical absorbance spectra of three natural dye

It is clear that maximum absorption occurs in the visible region. The absorption spectrum depends on anthocyanin content in each natural dye [28]. Thus anthocyanin content in Acalypha wilkesiana leaves extract is maximum whereas it is minimum in Gerbera jamesonii.

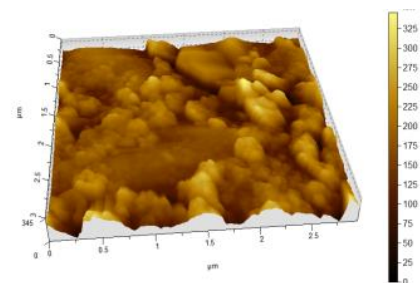

(a) Pure ZnS

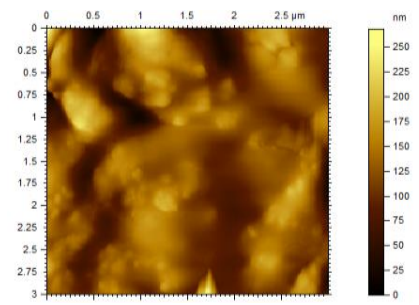

(c) ZnS with adsorbed Rosa indica (d) ZnS with adsorbed Acalypha wilkesiana plant extract dye

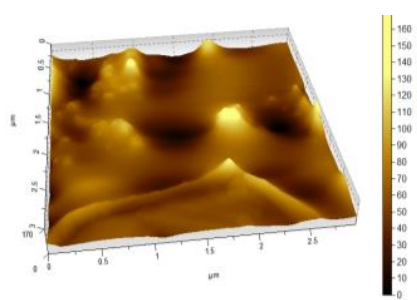

(b) ZnS with adsorbed Gerbera jamesonii plant extract dye

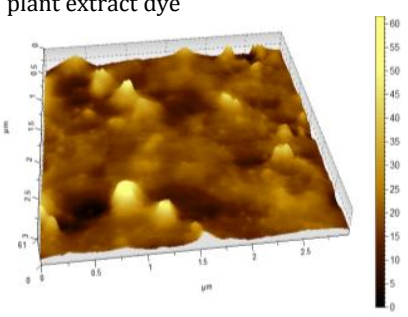

plant extract dye
Fig. 6 Atomic force microscopy of pure $\mathrm{ZnS}$ and $\mathrm{ZnS}$ with adsorped different plant extract dye 


\subsection{Atomic Force Microscopy Study}

The surface morphology of the dye adsorbed $\mathrm{ZnS}$ nanoparticles film and only nanoparticles film was analyzed using atomic force microscopy (AFM). The roughness of the plain ZnS film is found to be high. Roughness is reduced for dye adsorbed ZnS film shown in Fig. 6. This is probably due to the filling up of porosity in presence of dye. This is evident from 3D images of AFM.

\section{Table 1 Summarization of roughness}

\begin{tabular}{ll}
\hline Sample Name & Roughness (nm) \\
\hline Pure ZnS & 41.4 \\
ZnS with adsorbed Gerbera jamesonii plant extract dye & 34.5 \\
ZnS with adsorbed Rosa indica plant extract dye & 20.3 \\
ZnS with adsorbed Acalypha wilkesiana plant extract dye & 5.94 \\
\hline
\end{tabular}

\subsection{Current density (J) - Voltage (V) Characteristics}

The electrical characteristics of the dye sensitized solar cells were investigated under light conditions.

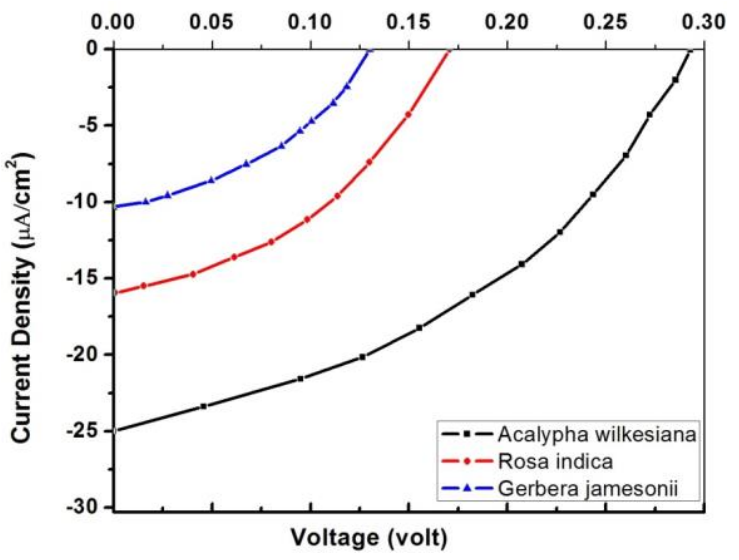

Fig. 7 Current density vs Voltage graph

Fig. 7 shows the measured J-V characteristics graph under illumination. From the figure we measure open circuit voltage and short circuit current. Fill factor and efficiency of the photovoltaic devices are determined from $\mathrm{J}-\mathrm{V}$ characteristics. Fill factor and efficiency can be calculated using the following relation,

$$
\mathrm{FF}=\frac{\mathrm{V}_{\mathrm{max}} \mathrm{J}_{\max }}{\mathrm{V}_{\mathrm{oc}} \mathrm{J}_{\mathrm{sc}}} \quad \text { and } \quad \eta=\frac{\mathrm{J}_{\mathrm{sc}} \mathrm{V}_{\mathrm{oc}} \mathrm{FF}}{\mathrm{P}_{\text {in }}}
$$

where $V_{\mathrm{mp}}, \mathrm{J}_{\mathrm{mp}}$ are voltage and current density at maximum power. $\mathrm{V}_{\mathrm{oc}} \mathrm{J}_{\mathrm{sc}}$ are open circuit voltage and short circuit current respectively, $\mathrm{P}_{\text {in }}$ is the incident power and $\eta$ is the efficiency.

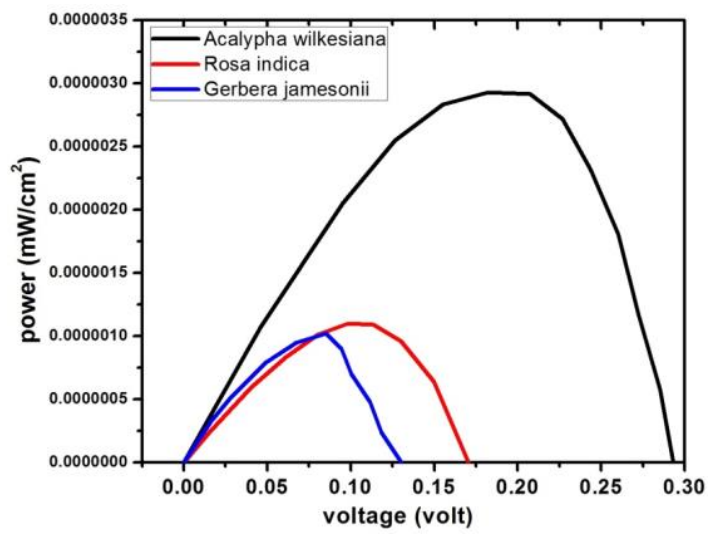

Fig. 8 P-V characteristics graph

Fig. 8 shows the power density (P) - voltage (V) curves corresponding to each J-V curve of different prepared DSSCs. The P-V curves give the value of maximum current density and maximum voltage at the maximum power point.
Table 2 Different parameters of dye sensitized solar cell obtained from J-V and P-V characteristics curve
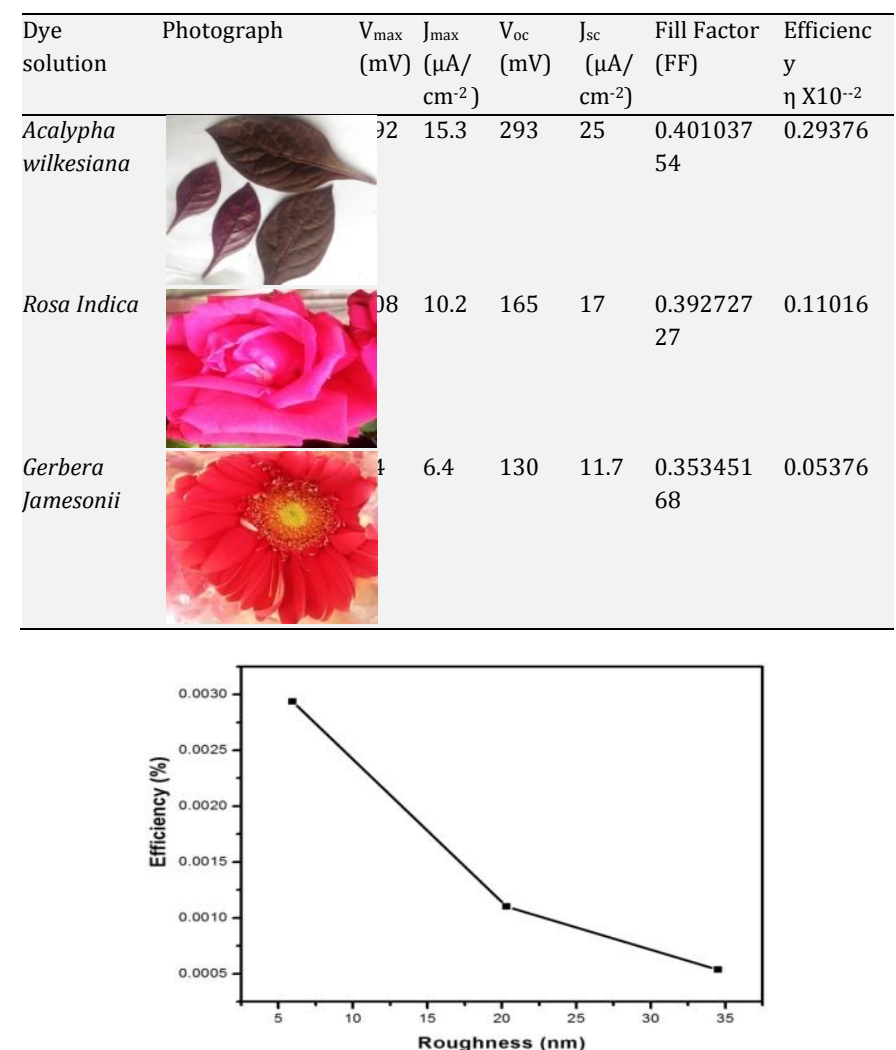

Fig. 9 Efficiency vs roughness graph

The J-V plot shows maximum power output in DSSC of Acalypha wilkesiana plant extract dye. This is possibly due to increased count of anthocyanin in Acalypha wilkesiana leaves extract dye compared to the other two dyes. It is shown that the efficiency decreases with the increase of roughness of $\mathrm{ZnS}$ with adsorped dye Fig. 9. The efficiency of the natural dye is lower than the other commercial chemical dyes like ruthenium ((Ru) dyes i.e. N3, N719 and Z907) [29].

Anthrocyanins mainly have $-\mathrm{OH}$ and -0 group and have no carboxyl group to chemically bind with the $\mathrm{ZnS}$ nanoparticle [30,31]. Hence, the anthocyanin dye greatly improved the optical absorbance of the $\mathrm{ZnS}$ nanoparticle.

\section{Conclusion}

ZnS nanoparticles are synthesized by a simple chemical reduction route for the fabrication of dye sensitized solar cell. Anthocyanin from natural dye, are used as a photosensitizer. ZnS nanoparticle used as photoanode and graphite paint is used as cathode. The efficiency of the different device is possibly low due to presence of anthocyanin as dye which does not bind well with $\mathrm{ZnS}$. Whereas the difference in efficiency are occur due to difference in light absorption seen from optical absorption study. It is clearly seen that with increase in film roughness the DSSC efficiency decreases. This may be due to low absorption of light from high roughness surface. The scattering of light increases for higher roughness surface.

\section{Acknowledgments}

Authors would like to thank Department of Science and Technology and University Grants Commission of Government of India for their constant support through Fund for Improvement of Science and Technology infrastructure in universities and higher educational institutions (FIST) and Special Assistance Program (SAP) to Department of Physics of Vidyasagar University.

\section{References}

[1] B. O'regan, M. Grätzel, A low-cost, high-efficiency solar cell based on dyesensitized colloidal $\mathrm{TiO}_{2}$ films, Nature 353. (1991)737-740.

[2] B.K. Lee, J.J. Kim, Enhanced efficiency of dye-sensitized solar cells by $\mathrm{UV}^{-\mathrm{O}_{3}}$ treatment of $\mathrm{TiO}_{2}$ layer, Curr. Appl. Phys. 9 (2009) 404-408.

[3] M. Dürr, A. Schmid, M. Obermaier, S. Rosselli, A. Yasuda, G. Nelles, Lowtemperature fabrication of dye-sensitized solar cells by transfer of composite porous layers, Nature Mater. 4 (2005) 607-611. 
[4] H. Matsui, K. Okada, T. Kawashima, T. Ezure, N.Tanabe, R. Kawano, M. Watanabe, Application of an ionic liquid-based electrolyte to a $100 \mathrm{~mm} \times 100$ mm sized dye-sensitized solar cell, J. Photochem. Photobiol. A Chem. 164 (2004) 129-135.

[5] S.S. Kim, Y.C. Nah, Y.Y. Noh, J. Jo, D.Y. Kim, Electrodeposited Pt for cost-efficient and flexible dyesensitized solar cells, Electrochim. Acta 51 (2006) 3814-3819.

[6] N. Robertson, Optimizing dyes for dye-sensitized solar cells, Angew Chem. Int. Ed. 45 (2006) 2339-2345.

[7] C. Xu, P.H. Shin, L. Cao, J. Wu, D. Gao, Ordered $\mathrm{TiO}_{2}$ nanotube arrays on transparent conductive oxide for dye-sensitized solar cells, Chem. Mater. 22 (2010) 143-148.

[8] T. Stergiopoulos, A. Valota, V. Likodimos, T. Speliotis, D. Niarchos, P. Skeldon, G.E. Thompson, P. Falaras, Dye-sensitization of self-assembled titania nanotubes prepared by galvanostatic anodization of $\mathrm{Ti}$ sputtered on conductive glass, Nanotechnol. 20 (2009) 365601-365609.

[9] T. Takagahara, K. Takeda, Theory of the quantum confinement effect on excitons in quantum dots of indirect-gap materials, Phys. Rev. B 46 (1992) 15578-15581.

[10] A.P. Alivisatos, Semiconductor clusters, nanocrystals, and quantum dots, Science 271 (1996) 933-937.

[11] W.E. Buhro, V.L. Colvin, Semiconductor nanocrystals: shape matters, Nature Mater. 2 (2003) 138-139.

[12] J. Ghrayeb, T.W. Jackson, R. Daniels, D.G. Hopper, Review of field emission display potential as a future (leap-frog) flat panel technology, Cockpit displays IV: Flat Panel displays for defense applications, Int. Soc. Optics Photon. 3057 (1997) 237-249.

[13] H. Kim, J.Y. Han, D.S. Kang, S.W. Kim, D.S. Jang, M. Suh, et al., Characteristics of $\mathrm{CuInS}_{2} / \mathrm{ZnS}$ quantum dots and its application on LED, J. Cryst. Growth 326 (2011) 90-93.

[14] R.H. Castillo, M. Acosta, I. Riech, G. Santana-Rodríguez, J. Mendez-Gamboa, et al., Study of $\mathrm{ZnS} / \mathrm{CdS}$ structures for solar cells applications, Optik-Int. J. Light Electron Opt. 148 (2017) 95-100.

[15] R.W. Xuan, J.P. Xu, X.S. Zhang, P. Li, C.Y. Luo, Y.Y. Wu, L. Li , Continuously voltagetunable electroluminescence from a monolayer of $\mathrm{ZnS}$ quantum dots, Appl. Phys. Lett. 98 (2011) 041907-041909.

[16] Y. Liang, H. Liang, X. Xiao, S. Hark, The epitaxial growth of $\mathrm{ZnS}$ nanowire arrays and their applications in UV-light detection, J. Mater. Chem. 22 (2012) 11991205.

[17] M. Li, X. Zhou, S. Guo, N. Wu, Detection of lead (II) with a "turn-on" fluorescent biosensor based on energy transfer from $\mathrm{CdSe} / \mathrm{ZnS}$ quantum dots to graphene oxide, Biosens. Bioelectron. 43 (2013) 69-74.
[18] J. Uddin, J.M.M. Islam, E. Karim, S.M.M. Khan, S. Akhter, E. Hoque, M.A. Khan, Preparation and characterization of dye sensitized solar cell using natural Dye extract from red amaranth (Amaranthus sp.) as sensitizer, Int. J. Thin Films Sci. Technol. 4 (2015) 141-146.

[19] E.J.W. Crossland, M. Nedelcu, C. Ducati, S. Ludwigs, M.A. Hillmyer, U. Steiner, H.J Snaith, Block copolymer morphologies in dye-sensitized solar cells: probing the photovoltaic structure- function relation, Nano Lett. 9 (2008) 2813-2819.

[20] T.S. Kang, A.P. Smith, B.E. Taylor, M.F. Durstock, Fabrication of highly-ordered $\mathrm{TiO}_{2}$ nanotube arrays and their use in dye-sensitized solar cells, Nano Lett. 9 (2009) 601-606.

[21] J.H. Yoon, S.R. Jang, R. Vittal, J. Lee, K.J. Kim, $\mathrm{TiO}_{2}$ nanorods as additive to $\mathrm{TiO}_{2}$ film for improvement in the performance of dye-sensitized solar cells, J. Photochem. Photobiol. A: Chem. 180 (2006) 184-188.

[22] S.H. Kang, S.H. Choi, M.S. Kang, J.Y. Kim, H.S. Kim, T. Hyeon, Y.E. Sung, Nanorodbased dye-sensitized solar cells with improved charge collection efficiency, Adv. Mater. 20 (2008) 54-58.

[23] K. Pan, Y. Dong, C. Tian, W. Zhou, G. Tian, B. Zhao, H. Fu, TiO 2 -B narrow nanobelt $/ \mathrm{TiO}_{2}$ nanoparticle composite photoelectrode for dye-sensitized solar cells, Electrochim. Acta 54 (2009) 7350-7356.

[24] H. Hug, M. Bader, P. Mair, T. Glatzel, Biophotovoltaics: natural pigments in dyesensitized solar cells, Appl. Ener. 115 (2014) 216-225.

[25] J.H. Yang, C.W. Bark, K.H. Kim, H.W. Choi, Characteristics of the dye-sensitized solar cells using $\mathrm{TiO}_{2}$ nanotubes treated with $\mathrm{TiCl}_{4}$, Materials 7 (2014) 35223532.

[26] W. Wang, I. Germanenko, M.S. E.l.-Shall, Room-temperature synthesis and characterization of nanocrystalline $\mathrm{CdS}, \mathrm{ZnS}$, and $\mathrm{Cd}_{\mathrm{x}} \mathrm{Zn}_{1-\mathrm{x}} \mathrm{S}$, Chem. Mater. 14 (2002) 3028-3033.

[27] K. Bera, S. Saha, P.C. Jana, Structural, optical and optoelectrical study of ZnS nanoparticles by varying reducing agent in chemical reduction route, J. Phys. Sci. 21 (2016) 167-175.

[28] S. Neill, K.S. Gould, Optical properties of leaves in relation to anthocyanin concentration and distribution, Canad. J. Bot. 77 (2000) 1777-1782.

[29] E. Nosheen, S.M. Shah, H. Hussain, G. Murtaza, Photo-sensitization of ZnS nanoparticles with renowned ruthenium dyes N3, N719 and Z907 for application in solid state dye sensitized solar cells: A comparative study, J. Photochem. Photobiol. B: Biol. 162 (2016) 583-591.

[30] M. Hosseinnezhad, S. Moradian, K. Gharanjig, Fruit extract dyes as photosensitizers in solar cells, Curr. Sci. 109 (2015) 953-956.

[31] S. Hao, J. Wu, Y. Huang, J. Lin, Natural dyes as photosensitizers for dyesensitized solar cell, Solar Energy 80 (2006) 209-214. 